such a case the risk of extradural haemorrhage is obvious.

(2) A fracture line crossing a paranasal sinus or the cribriform plate, alerting one to the risks of intracranial infection.

(3) The presence of air within the cranial cavity, providing evidence of a fistula between the subarachnoid space and the exterior.

(4) A fracture under an apparently trivial scalp wound making a compound fracture out of a seemingly innocent condition.

(5) Angulation of a bone fragment suggesting dural penetration.

Occasionally, unexpected dividends result from routine skull radiography. In the last six months in this centre my neuroradiological colleague has picked up one case of craniopharyngioma with suprasellar calcification and another of cerebellar tumour with suture diastasis, both previously unsuspected.

I am more than happy to answer for myself the question in the first sentence of the last paragraph of Dr. Burkinshaw's letter. Skull radiography is complementary to clinical observation and is an essential part of the examination of the patient with a head injury.-I am, etc.,

Neurosurgical Unit,

General Hospital

Middlesbrough, Teesside

Grant, D. N., Archives of Disease in Childhood,

$1971,46,651$.

\section{The Haemoglobinopathies}

SIR,-Because the article (5 February, p. 363) by Dr. G. W. G. Bird on haemoglobinopathies is so eminently useful and will be widely referred to, I would like to point out an error. Sickling is only caused by a haemoglobin with a $\beta$-chain which has in its sixth position a valine instead of a normally found glutamic acid. These are sickle-cell haemoglobin itself and another haemoglobin, known either as C Harlem or as C Georgetown, which has the same mutation in the $\beta$-chain as sickle-cell haemoglobin but in addition a substitution aspartic acid $\rightarrow$ asparagine in position 73. Haemoglobin Memphis, I, Barts, F, etc., do not in fact cause sickling. -I am, etc.,

M.R.C. Abnormal Haemoglobin Unit, Un. C. Abnormal Haemoglobin Unit,

Cambridge

\section{The Red Cell}

SIR,-Dr. G. W. G. Bird (29 January, p. 293) states that "the passage of water through the cell membrane is not a simple matter of osmosis as was once believed; it is exceptional for cells to be in osmotic equilibrium with their environment ... the cell has an active water transport system, which pumps water out of the cell."

These statements are not in accordance with recent work. It seems possible that they may have been based on some erroneous determinations of the freezing point of intracellular fluids which were current in the 1950s and which seemed to show hypertonicity in intracellular fluids. These determinations were, however, decisively disproved by several authors ${ }^{1-3}$ who showed that intracellular and extracellular fluids have the same osmotic pressure.

All recent studies of shrinking and swelling in erythrocytes ${ }^{4-7}$ have shown that the movement of water in and out of red cells is fundamentally osmotic in nature although there are considerable complications in regard to the osmotic pressure exerted by haemoglobin within the red cell. What is clear is that the osmotic pressure of haemoglobin is not simply proportional to its concentration, so that the effect of haemoglobin in the red cell is to limit the changes of volume which follow changes in the osmotic pressure of the plasma-for example, a $25 \%$ increase in plasma electrolytes such as can occur in hypernatraemic conditions will be followed by only a $16 \%$ shrinkage in red cell volume. This is a significant mechanism for the preservation of cellular volume, but it is wholly osmotic in nature.-I am, etc.,

Department of Anatomy

D. A. T. Dick

University of Anatomy

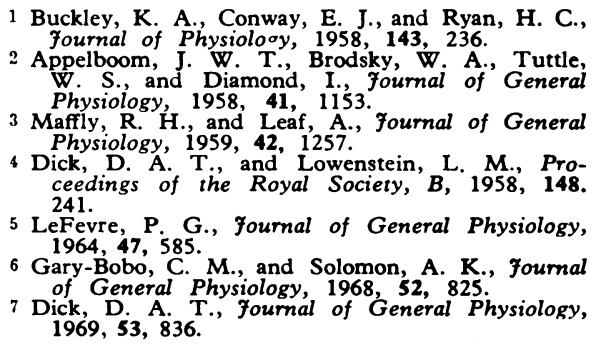

\section{Raised Protein in C.S.F. in} Hypertonic Dehydration

SIR,-A recent report $^{1}$ has recorded two instances of extreme elevation of cerebrospinal fluid protein in association with hypertonic dehydration, in the absence of any gross neurological abnormalities. The suggestion was made that vascular damage caused by hypernatraemia had allowed protein to leak from the damaged blood vessels to the brain parenchyma, and then to the C.S.F. We would like to record a similar case which we have recently observed.

A 2-month-old boy was admitted on 29 August 1971 because of irritability and anorexia. He had been well until the previous day, when he became irritable, pyrexial, and had developed diarrhoea. On examination at the time of admission he was found to be a very ill, dehydrated, and acidotic infant with a sunken fontanelle. Temperature was $36.7^{\circ} \mathrm{C}$ and weight 2.89 $\mathrm{kg}$. Both lungs were clear and there was no heart murmur. He was moving all four limbs, and no neurological defect was apparent. Blood culture was sterile and a rectal swab grew no pathogenic organisms.

Initial biochemistry was plasma $\mathrm{Na} 162$ $\mathrm{mEq} / 1 ., \mathrm{K} 5.6 \mathrm{mEq} / 1 ., \mathrm{Cl} 140 \mathrm{mEq} / 1$., $\mathrm{CO}_{2}$ content $13 \mathrm{mEq} / 1$, and urea $168 \mathrm{mg} / 100 \mathrm{ml}$. Capillary $\mathrm{pH}$ was $7 \cdot 12$, base excess 17 $\mathrm{mEq} / \mathrm{l}$, and $\mathrm{PcO}_{2} 38 \mathrm{~mm} \mathrm{Hg}$. A lumbar puncture was performed and clear fluid under normal pressure was obtained. Pandy's test was positive, and the C.S.F. protein was $410 \mathrm{mg} / 100 \mathrm{ml}$. C.S.F. sugar was $80 \mathrm{mg} / 100$ $\mathrm{ml}$. The C.S.F. contained 3 W.B.C. $/ \mathrm{mm}^{3}$ and was sterile on culture.

The baby was rehydrated with $5 \%$ dextrose in quarter-strength saline. A 10day course of intramuscular kanamycin was given. The child improved rapidly, and at no time was there any suspicion of neurological pathology such as subdural haematoma or cerebral haemorrhage. A repeat C.S.F. examination was undertaken 11 days after admission, when the C.S.F. protein was found to be $54 \mathrm{mg} / 100 \mathrm{ml}$. Sugar content was $56 \mathrm{mg} / 100 \mathrm{ml}$; the C.S.F. contained 90 R.B.C. $/ \mathrm{mm}^{3}$ and was sterile on culture. The child was discharged well 12 days after admission.

We have surveyed the records of children with hypertonic dehydration admitted to one of the units of this hospital over the period 1968-71. A total of 71 cases were admitted, and 30 children had lumbar puncture and C.S.F. protein estimation. The range of protein levels was $22 \mathrm{mg} / 100 \mathrm{ml}$ to 68 $\mathrm{mg} / 100 \mathrm{ml}$.

We would be interested to know of any other instances or explanations of extreme elevation of C.S.F. protein in association with hypertonic dehydration.-We are, etc.,

KRISHNA M. Goel MaLCOLM K. LiNDSAY

Royal Hospital for Sick Children

Glasgow C.3

Shavwitz, B. A.. American fournal of Diseases
of Children, 1970, 120,84.

Vasectomy

SIR,-Mr. Philip Whitehead (Derby, North, Lab.) in moving the second reading of the National Health Service (Family Planning) Amendment Bill is reported as saying that: "the Bill dealt with vasectomy only, which was cheap, simple, and $100 \%$ reliable" (29 January, p. 321). It is reasonably cheap and perhaps usually simple, but in the experience of the Medical Protection Society it is certainly not $100 \%$ reliable, for the Society has had reported to it several cases where the operation has been unsuccessful.-I am, etc.,

London W.

H. A. Constable Medical Protection Society

\section{Hospital Staffing}

SIR,-At this time the question to be asked is: Can a busy acute unit admitting and dealing with seriously ill patients be manned for any amount of time by only a preregistration doctor with supervision at a distance by a consultant, who may be busily engaged elsewhere or may be living 10 miles $(16 \mathrm{~km})$ from the hospital in question? To anyone engaged in clinical practice the answer is patently obvious, but to the nonclinical doctors manning the Department of Health the problem seems to have been completely disregarded over the last few years. Despite the protestations from responsible doctors in some hospitals no effort has been made to provide patients with proper care by experienced junior staff. The irresponsible registrar freeze continues.

We are all awaiting the commencement of the Central Manpower Committee, but there is considerable concern throughout the country that this fundamental issue of proper staffing by experienced junior doctors is to be ignored, with the sole effort being made to provide a career structure with early consultant grading.

Again it is emphasized that over half of the junior staff are from overseas and require registrar posts not only for their theoretical and practical training but also to allow them to take various specialist qualifications. Is this postgraduate training for these doctors to be curtailed?

I think now is the time for the Depart- 